Int. J. Dev. Biol. 57: 553-564 (2013)

doi: $10.1387 / \mathrm{ijdb} .130189 \mathrm{wf}$

\title{
The moss Physcomitrella patens: methods and tools from cultivation to targeted analysis of gene function
}

\author{
CHRISTOPH STROTBEK", STEFAN KRINNINGER ${ }^{\#}$ and WOLFGANG FRANK* \\ Ludwig-Maximilians-University Munich (LMU), Faculty of Biology, Department Biology I, \\ Plant Molecular Cell Biology, LMU Biocenter, Germany
}

\begin{abstract}
To comprehensively understand the major processes in plant biology, it is necessary to study a diverse set of species that represent the complexity of plants. This research will help to comprehend common conserved mechanisms and principles, as well as to elucidate those mechanisms that are specific to a particular plant clade. Thereby, we will gain knowledge about the invention and loss of mechanisms and their biological impact causing the distinct specifications throughout the plant kingdom. Since the establishment of transgenic plants, these studies concentrate on the elucidation of gene functions applying an increasing repertoire of molecular techniques. In the last two decades, the moss Physcomitrella patens joined the established set of plant models based on its evolutionary position bridging unicellular algae and vascular plants and a number of specific features alleviating gene function analysis. Here, we want to provide an overview of the specific features of $P$. patens making it an interesting model for many research fields in plant biology, to present the major achievements in $P$. patens genetic engineering, and to introduce common techniques to scientists who intend to use $P$. patens as a model in their research activities.
\end{abstract}

KEYWORDS: Physcomitrella patens, genetic engineering, gene function analysis, reverse genetics, homologous recombination

\section{Introduction}

Thirty years ago, the first transgenic plants had been generated and it took another eight years until the first transgenic moss - Physcomitrella patens - had been established (Schaefer et al., 1991). Since then, it took many efforts to devise new strategies and tools to facilitate research in moss biology. The discovery of the highly efficient integration of foreign DNA by homologous recombination $(\mathrm{HR})$ in P. patens (Kammerer and Cove, 1996) enabled the elaboration of gene targeting as a precise tool to genetically manipulate any chosen genomic DNA sequence (Schaefer and Zrÿd, 1997). These milestones led to the first targeted knockout mutants in $P$. patens (Girke et al., 1998; Strepp et al., 1998) that opened a new era of reverse genetics. With the development of feasible and reliable transformation methods, the possibilities in genetic engineering, and the phylogenetic position of mosses between unicellular photosynthetic eukaryotes and seed plants, $P$. patens came into the focus of plant biology research to address multifaceted scientific questions in evolutionary and developmental biology. The exploration of the encoded genetic information in $P$. patens was strongly supported by the completed genome sequencing (Rensing et al., 2008) and enabled comparative studies to gain knowledge about land plant evolution. Nowadays, manifold elegant techniques are available for detailed analysis of gene functions in $P$. patens. Together with its favourable features for laboratory experimental work, $P$. patens has become a versatile model plant.

\section{The life cycle of $P$. patens}

The life cycle of $P$. patens comprises two alternating heteromorphic and heterophasic generations (Fig. 1A). In contrast to seed plants, the gametophyte represents the predominant generation in mosses. The gametophytic generation starts with the germination of a haploid spore (Fig. 1B) that forms a branched filamentous protonema tissue by apical growth (Fig. 1C). The protonema consists

Abbreviations used in this paper: amiRNA, artificial miRNA; DSB, double-strand break; EST, expressed sequence tag; GFP, green fluorescent protein; HR, homologous recombination; IR, illegitimate recombination; miRNA, microRNA; MYA, million years ago; NHEJ, non-homologous end joining; PCR, polymerase chain reaction; PEG, polyethylene glycol; RNAi, RNA interference; sRNA; small non-coding RNA; siRNA, short interfering RNA.

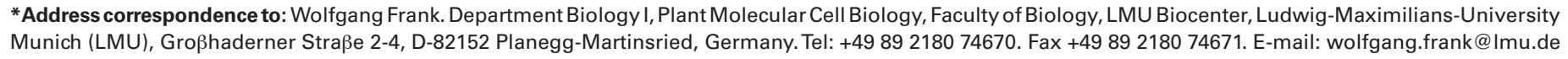

\#Note: Both authors contributed equally to this work

Final, author-corrected PDF published online: 16 October 2013.

ISSN: Online 1696-3547, Print 0214-6282 
of two distinct cell types: the chloroplast enriched chloronema cells with perpendicular cross-walls and the caulonema cells containing few chloroplasts and with oblique cross-walls. The transition from the juvenile protonema tissue to the adult gametophore is initiated by the formation of meristematic buds with three-faced apical cells. These buds develop into gametophores (Fig. 1D) with a shoot-like stem bearing leaf-shaped phylloids and rhizoids at its base (Fig. $1 \mathrm{E})$. Sexual reproduction is initiated by the development of both female (archegonia) and male (antheridia) sex organs at the tip of the gametophore (monoecious species) (Fig. 1F). Within the antheridia, motile spermatozoids are formed that are capable to
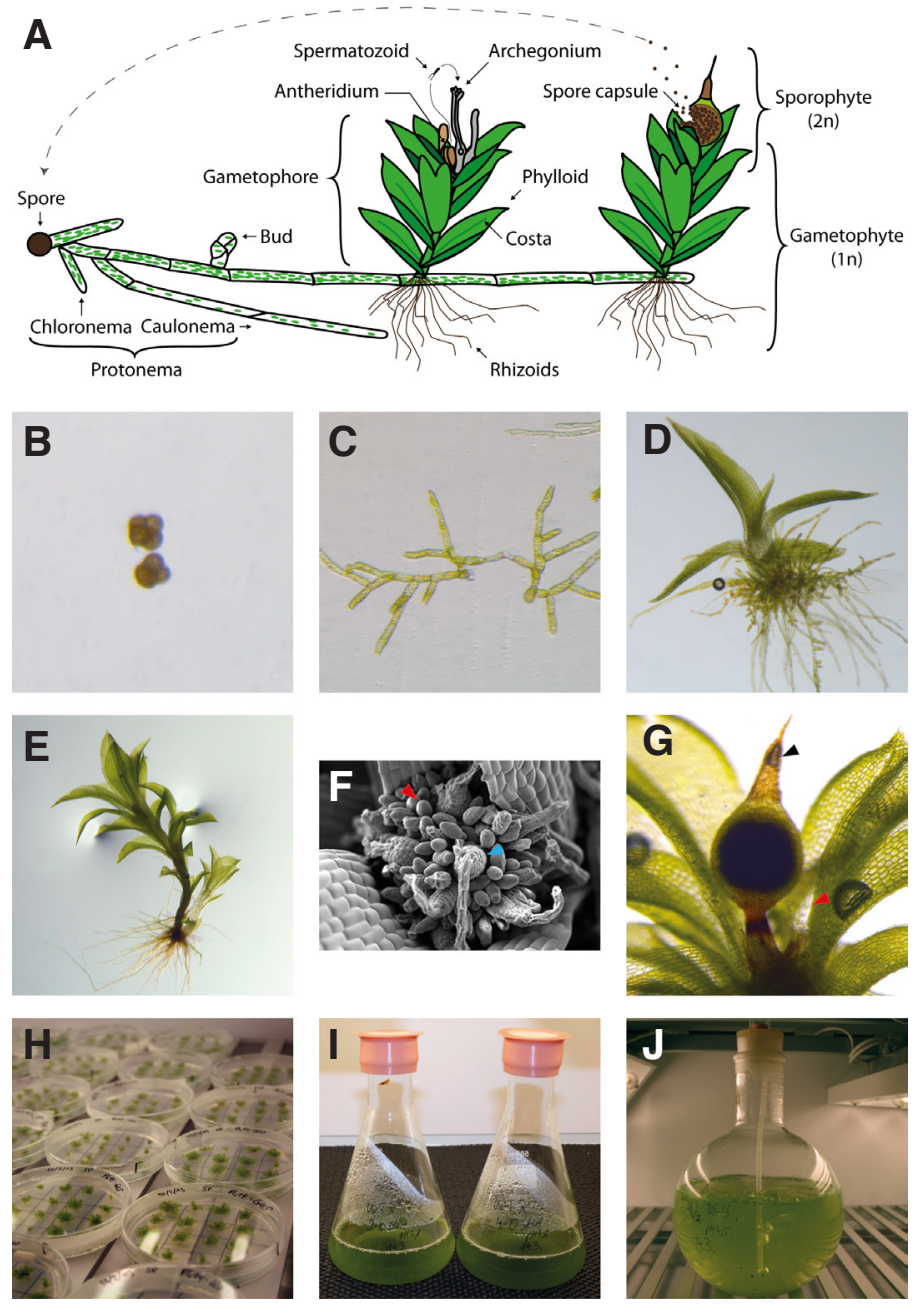

Fig. 1. The life cycle and cultivation of $\boldsymbol{P}$ patens. (A) Scheme of the $\mathrm{P}$. patens life cycle. (B) Tetrads of haploid spores derived from meiotic cell divisions of spore mother cells released from the spore capsule of the sporophyte. (C) Branched protonema tissue grown in liquid culture. (D) Developing gametophore. (E) Gametophores atearly (right) and late developmental stages with rhizoids at their base. (F) Scanning electron micrograph of gametangia (top view). Antheridia and archegonia are indicated by red and blue arrows, respectively. (G) Fully developed sporophyte surrounded by phylloids of the gametophore. At the base unfertilised archegonia are visible (red arrow) and dark spores inside the spore capsule. On top of the sporophyte the remaining tissue of the archegonium forms the calyptra (black arrow). (H) Petri dishes with solidified media and moss colonies. (I) Erlenmeyer flasks with liquid media and protonema culture. (J) Air-ventilated flask with liquid media and protonema culture. move in the presence of water where they fertilise the single egg cell within the archegonium. Upon fertilisation, the diploid sporophyte develops from the zygote building up a short seta and an apical spore capsule within which meiosis takes place and hundreds of haploid spores are produced (Fig. 1G). After ripening, the spore capsule breaks up and releases the spores for propagation. On top of the spore capsule the residual tissue of the archegonium forms the characteristic calyptra.

\section{Aspects of plant evolution - $P$. patens as a link between green algae and seed plants}

One of the reasons to study the biology of mosses, in general, and $P$. patens, in particular, lies in the key position of mosses in plant evolution and the associated gain of specific features connecting the aquatic and terrestrial mode of life. The first features of the basic body plan of higher plants evolved more than 500 million years ago (MYA) within the Charophyta: a three-dimensional and multicellular gametophyte that is formed by apical meristematic cells and consists of cells with cellulosic cell walls that are interconnected by plasmodesmata (Fig. 2). With the transition from aquatic to terrestrial life approximately 470 MYA, the first land plants (Embryophyta) evolved a multicellular diploid sporophyte that is protected by an epidermal tissue. Later, 440 MYA, the basal vascular system of the Tracheophyta raised with specialised water-conducting cells, one of the prerequisites for an extended longitudinal growth, and the sporophytic generation became predominant. Approximately 400 MYA, the first seeds evolved with the earliest representatives of Spermatophytina and, with the development of flowers 300 MYA, the massive radiation of the angiosperms (Magnoliophyta) occurred. In view of this evolution course, representative model species of the respective clades were chosen for genome sequencing projects to link the most relevant inventions in plant evolution to changes in the genetic repertoire (Floyd and Bowman, 2007). Within the basal land plants, the moss $P$. patens holds a key position bridging the gap between aquatic green algae, such as Chlamydomonas reinhardtii, and early tracheophytes, such as Selaginella moellendorffii, or even higher seed plants, such as Arabidopsis thaliana. Given the phylogenetic position of $P$. patens, the specific adaptations to the new environmental conditions required for the transition from aquatic to terrestrial life can be studied within this model plant. Abiotic stresses caused by the limited water availability on land, strong irradiation by sun light, and varying temperatures necessitated extensive modifications from signalling over physiological processes to modified body plans (Floyd and Bowman, 2007). By comparative analysis of gene function in the species representing different evolutionary steps, it is possible to differentiate between gene families that emerged recently in the course of evolution (such as by adaptation) and conserved gene families encoding proteins with fundamental functions.

\section{Qualities and benefits of $P$. patens in its use as a model plant}

Three aspects are important for the qualities and benefits of $P$. patens in its use as a model plant, namely the possibilities for cultivation and physical manipulation, the available knowledge on the genetic information encoded in $P$. patens and, in particular, the established techniques to modify $P$. patens genetically. 
The cultivation of $P$. patens is reasonably simple, except for the precautions for axenic cultivation. In fact, in approximately four months, $P$. patens can go through its entire life cycle in a Petri dish containing a simple solidified mineral medium (see below). A striking feature simplifying considerably its cultivation is that almost any tissue or single cell is capable to regenerate into intact plants on hormone-free media. Thus, the generation of transgenic lines after polyethylene glycol (PEG)-mediated transformation of protoplasts with DNA is easy and a single plant can be cloned and propagated unlimitedly to provide continuously genetically identical plant material for analysis (Hohe et al., 2002a). Furthermore, $P$. patens is directly accessible to manipulations or diverse treatments because most of the tissues consist of single cell layers (phylloids) or filaments (protonema) that are able to take up water and nutrients over the whole surface. Therefore, $P$. patens is a suitable model plant to analyse phytohormone action (Decker et al., 2006) and responses to biotic (Lehtonen et al., 2012) as well as abiotic stresses (Frank et al., 2005).

The functional analysis of developmental processes is straightforward by the almost translucent body and the tightly structured number of differentiated cells in the simple body plan of $P$. patens (Menand et al., 2007; Harrison et al., 2009). In addition, these features allow us to study the spatial control of gene expression, protein localisation, and interaction by using reporter genes directly in vivo (Nishiyama et al., 2000; Nakaoka et al., 2012).

Regarding the available knowledge on the genetic information encoded in P. patens, novel techniques for functional gene analysis in $P$. patens had been developed in the early 80 s and improved in the following years (Fig. 3). The increasing demand for sequence information from genomic DNA as well as transcripts had been first

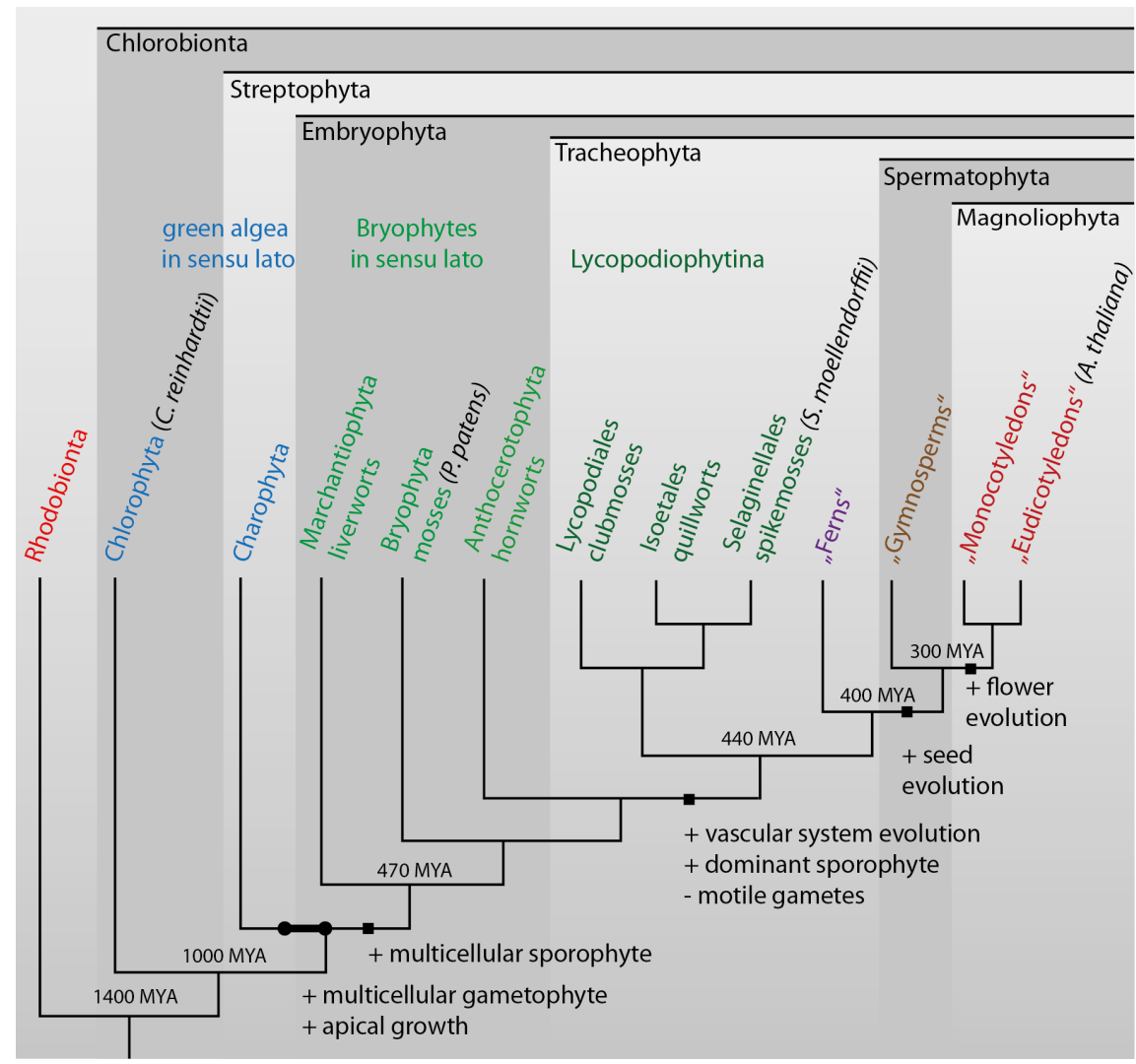

TABLE 1

\section{GENOME SIZE AND GENE NUMBERS OF THE P. PATENS PLASTID AND MITOCHONDRION GENOMES}

\begin{tabular}{lcccc} 
Genome & Genome size & Protein-coding genes & tRNA genes & rRNA genes \\
\hline Plastid & $122.89 \mathrm{kbp}$ & 83 & 31 & 3 \\
Mitochondrion & $105.34 \mathrm{kbp}$ & 42 & 24 & 3 \\
\hline
\end{tabular}

TABLE 2

\section{COMPARISON OF GENOME SEQUENCING RESULTS}

\begin{tabular}{lccc} 
Features & $\begin{array}{c}\text { P. patens } \\
\text { (version 1.6) }\end{array}$ & $\begin{array}{c}\text { S. moellendorffii } \\
\text { (version 1.0) }\end{array}$ & $\begin{array}{c}\text { A. thaliana } \\
\text { (TAIR10) }\end{array}$ \\
\hline $\begin{array}{l}\text { Chromosomes } \\
\text { Genome size (assembled }\end{array}$ & $\sim 480 \mathrm{Mbp}(1985)$ & $\sim 106 \mathrm{Mbp}(768)$ & $\sim 120 \mathrm{Mbp}$ (resolved to 5) \\
scaffolds) & & & \\
$\begin{array}{l}\text { Predicted protein coding } \\
\text { genes }\end{array}$ & 32,275 & 22,285 & 27,416 \\
Total genes & 33,953 & $\mathrm{~N} . \mathrm{D}$. & 33,602 \\
MIR genes & 229 & 58 & 299 \\
\hline
\end{tabular}

P. patens (Rensing et al., 2008; Zimmer, 2013), Selaginella moellendorffii (Banks et al., 2011) and A. thaliana (The Arabidopsis Information Resource, 2013)

N.D., not determined.

addressed with the generation of genomic libraries used to identify homologues in P. patens of known genes from other species (Long et al., 1989). Concerning transcript sequences, the first set of 82 expressed sequence tags (ESTs), ranging in size from 0.1 to 1 $\mathrm{kb}$, was generated from cytokinin-treated protonema tissue and provided sequence information useful for gene targeting experiments and bioinformatic gene analysis (Reski, 1998). In the following years, the released ESTs reached more than 100,000 sequences derived from varying tissues and treatments. These EST sequences were assembled into virtual transcriptomes that were used for computational gene annotation and analysis (Lang et al., 2005; Rensing et al., 2005). Thereby, more than $63 \%$ of 26,123 assembled transcripts were annotated and associated with gene ontology terms, revealing that gene products related to metabolism are overrepresented in $P$. patens in comparison to seed plants. Furthermore, more than $30 \%$ of the assembled gene products have detectable homologues in seed plants, whereas a high proportion of genes have their closest homologues in unicellular eukaryotes and even in other taxonomic groups, such as bacteria, fungi, and metazoa.

This transcriptome analysis was based on EST sequences derived mainly from partially sequenced cDNAs that are often incomplete in coding sequences and lack information from transcripts not represented in the RNA pools used

Fig. 2. Phylogenetic tree. Phylogenetic tree representing the evolutionary relationships from red algae (Rhodobionta) to angiosperms (Magnoliophyta). Selected model species representing taxa with phylogenetic key positions in land plant evolution are in parentheses. (Modified from Pires and Dolan, 2012). 
TABLE 3

\section{P. PATENS GENE MODELS BASED ON THE GENOME ANNOTATION VERSION 1.6 (ZIMMER, 2013)}

\begin{tabular}{ll} 
Genome feature & Number \\
\hline Predicted protein-coding genes & $32,275(100 \%)$ \\
Loci with transcript evidence & $26,722(\sim 83 \%)$ \\
Protein-coding transcripts & 38,357 \\
Alternatively spliced genes & $3,500(\sim 10 \%)$ \\
Genes with 5' and 3' UTR annotation & $15,757(\sim 49 \%)$ \\
Genes with assigned GO term & $18,786(\sim 58 \%)$ \\
Biological processes & $10,326(\sim 32 \%)$ \\
Cellular components & $14,839(\sim 46 \%)$ \\
Molecular functions & $13,110(\sim 41 \%)$ \\
\hline
\end{tabular}

UTR, untranslated region; GO, gene ontology.

to generate the cDNAs. Also sequence information from genomic DNAthat includes regulatory elements, such as promoters, terminators, enhancers, and further regulatory elements, was still missing. Based on the EST-derived transcriptome, the first microarrays were designed and used for comparative transcriptome analyses in $P$. patens, focusing on the identification of genes that respond to osmotic stress and the phytohormone abscisic acid (Cuming et al., 2007; Richardt et al., 2010).

Complete genome sequences became at first available from mitochondria and plastids (Sugiura et al., 2003; Terasawa et al., 2007) (Table 1). Phylogenetic comparisons of conserved mitochondrial genes confirmed the bryophyte clade as sister group to flowering plants. Finally, the complete nuclear genome sequence of $P$. patens filled the major gap in sequence knowledge and provided the breakthrough for reverse genetics (Rensing et al., 2008) (Table 2). Several conclusions were drawn from the first analysis of the complete genome sequence regarding the adaptations and changes during land plant evolution. For the last common ancestor of land plants, a loss of genes associated with aquatic life and dynein-mediated transport was interconnected with a gain of genes associated with terrestrial life (photoreception, abiotic stress tolerance, and transport) and hormone signaling (abscisic acid, auxin, and cytokinin).

With the advent of next-generation sequenc-

Fig. 3. $P$ patens genetics milestones aligned with selected general ones. The major foundations for reverse genetics are marked in blue (No. 12,13, and 14), the first targeted knockouts in orange (No. 16) and the P. patens genome release in green (No. 25). 1, Bevan et al., (1983), Fraley et al., (1983), and Zambryski et al., (1983); 2, Mullis et al., (1986); 3, Smith et al., (1986); 4, Adams et al., (1991); 5, Fleischmann et al., (1995); 6, Fire et al., (1998); 7, Collins et al., (2004); 8, Kaul et al., (2000); 9, Merchant et al., (2007); 10, Banks et al., (2011); 11, Long et al., (1989); 12, Schaefer et al., (1991); 13, Kammerer and Cove (1996); 14, Schaefer and Zrÿd (1997); 15, Reski et al., (1998); 16, Girke et al., (1998) and Strepp et al., (1998); 17, Hofmann et al., (1999); 18, Rensing et al., (2002); 19, Bezanilla et al., (2003); 20, Sugiura et al., (2003); 21, Sugiura and Sugita (2004); 22, Axtell et al., (2006); 23, Cuming et al., (2007); 24, Terasawa et al., (2007); 25, Rensing et al., (2008); 26, Nishiyama et al., (2012). ing technologies, the $P$. patens transcriptome was quantitatively explored in more detail. Deep sequencing of small non-coding RNAs (sRNAs) from the wild type, the DICER-LIKE 3 (DCL3)deficient $\triangle P p D C L 3$ and $\triangle P p D C L 4$ mutants, enlightened the origin and biogenesis of specific sRNA classes (Cho et al., 2008; Arif et al., 2012) and deep sequencing of 5 ' ends of uncapped mRNAs (degradome) revealed microRNA (miRNA) biogenesis and target cleavage at a genome-wide resolution (Addo-Quaye et al., 2009). Recently, deep sequencing of 5' mRNA ends was used for a quantitative genome-wide expression analysis to study changes in gene expression during the reprogramming of leaf cells upon phylloid excision (Nishiyama et al., 2012).

Taken together, the bioinformatic analysis of the available genome sequence in combination with transcriptome data resulted in increasingly precise gene annotations (Table 3). The last aspect refers to transformation methods, the principle of $\mathrm{HR}$ and the diverse techniques that are established to genetically modify $P$. patens. These points will be discussed in more detail in the following sections.

\section{Cultivation and growth}

As for other model plants, the analysis of specific biological processes requires axenic cultivation. Therefore, spores or gametophores can be easily sterilised by, for instance, sodium

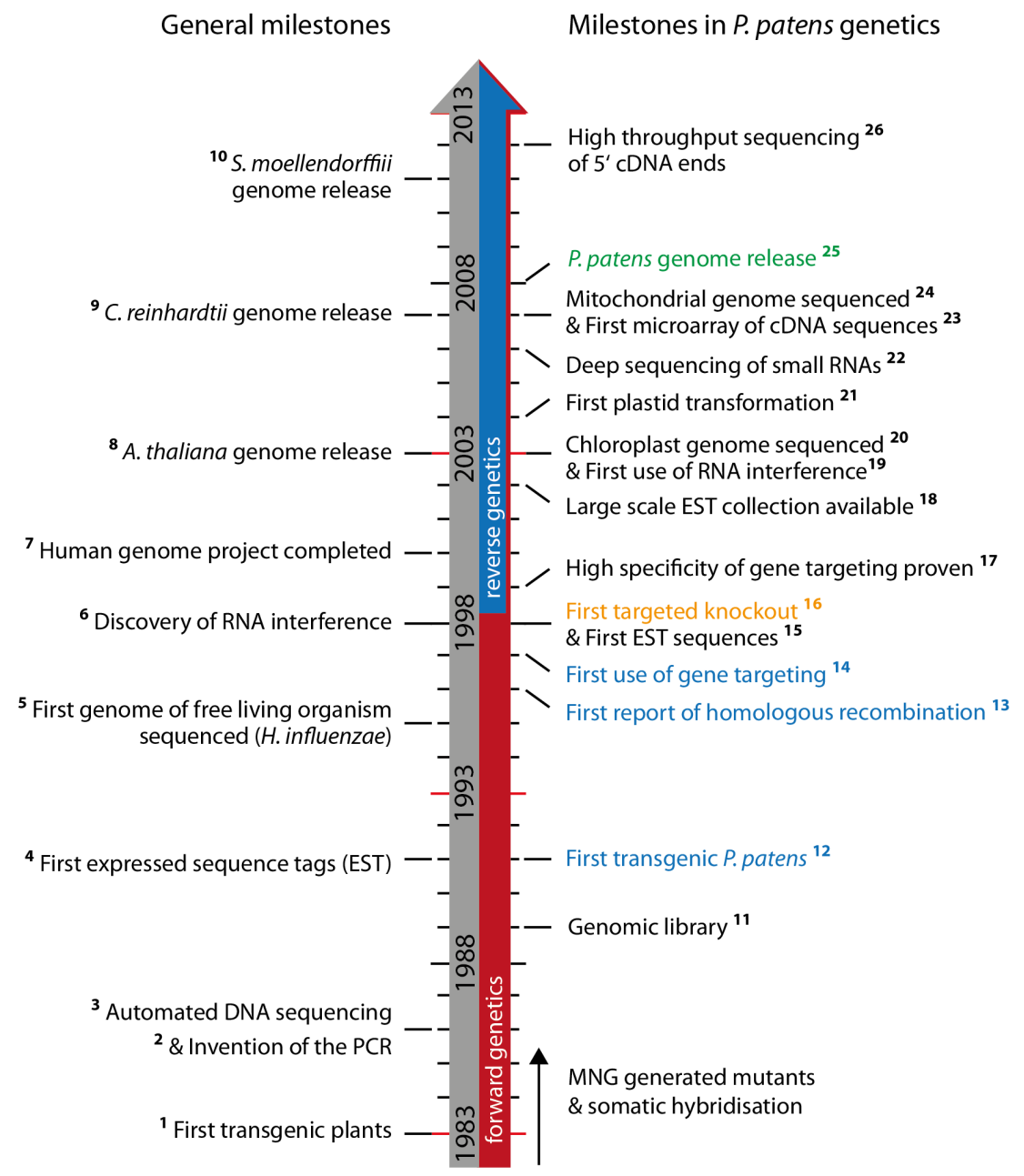


A

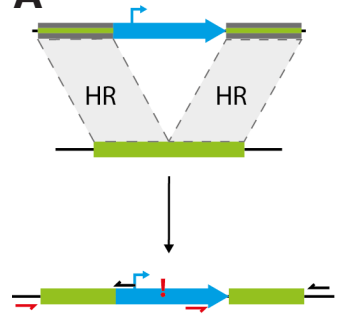

integration by $\mathrm{HR}$ (correct gene targeting)

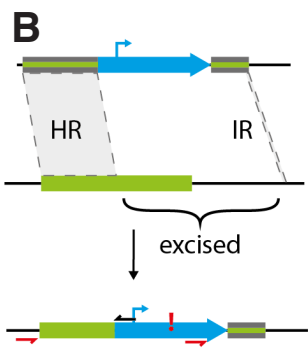

integration by $\mathrm{HR}$ and IR (partial gene targeting)

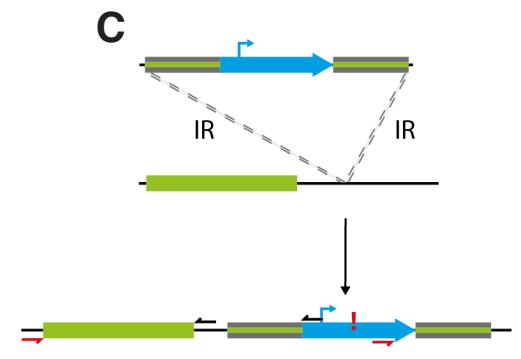

random integration by $I R$ (no gene trageting)

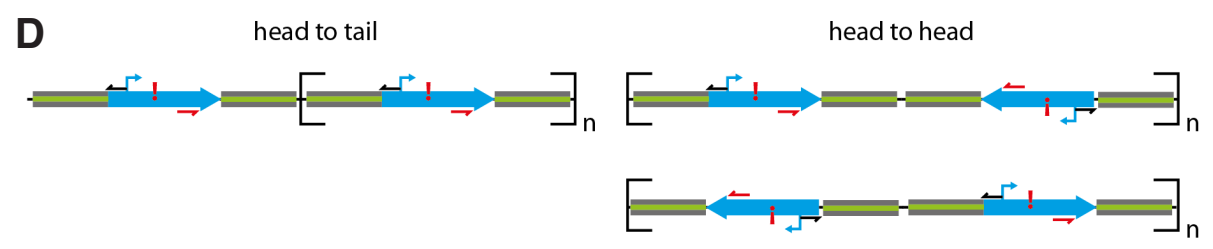

tail to tail
Fig. 4. Principle of gene targeting mechanisms and possible side effects. (A) Integration of $5^{\prime}$ and $3^{\prime}$-flanking region via $H R$ resulting in precise gene targeting. (B) Partial gene targeting resulting from $5^{\prime}$ and $3^{\prime}$ integration via $H R$ and via IR, respectively, caused by asymmetric flanking regions. (C) Random integration via IR. The endogenous region remains unchanged. (D) Possible formation of concatemers prior to integration. Primers and their positions used to analyse integration events are indicated by red (forward) and black (reverse) arrows. Exclamation marks indicate a unique restriction site present in the construct used for Southern blot analyses.

hypochlorite, and subsequently germinated and cultured on solidified mineral medium (Beike et al., 2010). Once an axenic culture has been started, $P$. patens also can be cultivated in liquid media by the inoculation of plant material and regular mechanical disruption. For photoautotrophic growth of $P$. patens different types of growth media are utilized. As a complex solid growth medium, sterilised peat soil is used and, commonly, either liquid or solidified simple mineral media basically containing $\mathrm{KH}_{2} \mathrm{PO}_{4}$, $\mathrm{MgSO}_{4}, \mathrm{Ca}\left(\mathrm{NO}_{3}\right)_{2}$, or $\mathrm{KNO}_{3}$ and $\mathrm{FeSO}_{4}$ with a pH ranging from 4.5 to 6.5 as defined growth media (Reski et al., 1994). These media are often supplemented with defined microelements (Ashton et al., 1979; Nishiyama et al., 2000) and, depending on the need of the cultivated line, with vitamins or a carbon source (Schween et al., 2003). Light and temperature are controlled to maintain standardised culture conditions. Routinely, $P$. patens is grown at $25^{\circ} \mathrm{C}$ under long-day conditions with $16 \mathrm{~h}$ light/8 $\mathrm{h}$ dark cycles or continuous light at a light intensity ranging from 30 to $80 \mu \mathrm{mol} / \mathrm{m}^{2}$ s. Formation of sporophytes is enhanced at $15^{\circ} \mathrm{C}$ under short-day conditions with $8 \mathrm{~h}$ light at an intensity of $20 \mu \mathrm{mol} / \mathrm{m}^{2} \mathrm{~s}$ (Hohe et al., 2002b).

Petri dishes or multiwell plates are the most cost-effective containers for cultivation on solid media, but there are no limitations for other types. For sub-cultivation, small pieces of any tissue, e.g. protonema or gametophores, can be transferred onto fresh media. Solid media can be covered with cellophane sheets that are permeable for water and nutrients, simplifying the transfer and subculture of plant material onto varying growth media, for instance, antibiotics-containing medium to select for transgenic lines. The cultivation in liquid media can be up-scaled ranging from growth in multiwell plates, Erlenmeyer flaks, ventilated flasks up to controlled bioreactors with volumes of up to 100 L (Lucumi et al., 2005; Parsons et al., 2012) (Fig. $1 \mathrm{H}-\mathrm{J}$ ).

\section{$P$. patens and its potential use in bio- technology}

In addition to basic research $P$. patens also emerged as a new plant model for biotechnological applications, in particular for the expression of therapeutic and diagnostic recombinant proteins (Koprivova et al., 2004; Parsons et al., 2012). The number of recombinant proteins produced in plant systems increases rapidly and several plant-made pharmaceutics have meanwhile reached the stage of clinical studies (Faye and Gomord, 2010). In comparison to unicellular expression systems, such as bacteria or yeast, $P$. patens is as a higher multicellular eukaryote, able to perform extensive posttranslational protein processing, including glycosylation, disulphide bridge formation, folding, and multimeric assembly (Raskin etal., 2002; Gomord and Faye, 2004). In addition, compared to mammalian cell line expression systems, the required process technology and the associated production costs can be significantly reduced. Furthermore, contamination of plant-based production systems by human pathogens can be almost entirely excluded (Raskin et al., 2002; Fischer et al., 2004). An additional advantage with respect to the production of recombinant proteins is that $P$. patens can be photoautotrophically cultivated in a bioreactor under constant conditions (Decker and Reski, 2004). The secretion of the recombinant proteins into simple mineral media reduces the purification and downstream processing costs.

One drawback of plant-made proteins is that $\mathrm{N}$-glycans from plant cells differ considerably from those produced in mammalian cell types and, thus, may cause allergic reactions (Foetisch et al., 2003). However, improved $P$. patens strains for the expression of recombinant proteins have been generated by the targeted knockout of plant-specific glycoslytransferases that lack plant immunogenic $\mathrm{N}$-glycans (Koprivova et al., 2004). Furthermore, the glycosylation pattern was humanised following a knockout-knockin strategy in which the plant-specific 1,3-fucosyltransferase and 1,2-xylosyltransferase were replaced by the human 1,4-galactosyltransferase, resulting in a proper human-type glycosylation of a recombinantly produced protein that lacked immunogenic residues (Huether et al., 2005). Further, as another proof of concept, the biologically active human vascular endothelial growth factor was produced in genetically engineered moss cells (Decker and Reski, 2012). These specific features make $P$. patens highly attractive, not only as model organism for the scientific community, but also for the pharmaceutical industry as a producer of biopharmaceutical agents.

\section{Homologous recombination}

Currently, two main pathways are known for the repair of DNA double-strand breaks (DSBs) in plant cells. Both the non- 
homologous end joining (NHEJ) and the HR, are highly conserved DNA DSB repair mechanisms (Pâques and Haber, 1999) that can be found in all three domains of life and allow a cell to keep its genome fully functional (Sung and Klein, 2006; Roth et al., 2012). The NHEJ operates via illegitimate recombination (IR) without sequence-specific requirements, whereas HR depends on sequence similarity for the DSB repair (Fig. 4).

The two predominant models of HR are fundamentally similar and are both based on homologous sequence regions (Gorbunova and Levy, 1999). Whereas the size of the homologous regions determines homologous or non-HR by single-strand annealing (Puchta, 2005), the type of strand invasion specifies whether filler DNA (via NHEJ) or gene conversion (via HR) takes place during synthesis-dependent strand annealing (Gorbunova and Levy, 1999). During DSB repair, the chromosomes advance pairwise, Holliday junctions are formed, and proteins fix the DSB (Sung and Klein, 2006). Simple organisms, such as yeast or lower plants, prefer homologous regions for the DNA DSB repair (Gorbunova and Levy, 1999), but higher organisms, such as seed plants or mammals, seem to favour microhomologies and NHEJ for DSB repair (Puchta, 2002; Kamisugi et al., 2006). For example, in flowering plants, the rate for HR events is dramatically lower than that for IR. Only one out of 10,000 recombination events occur by HR, while the remaining recombination events occur via IR (Britt and May, 2003). In P. patens, foreign DNA harbouring homologous sequence stretches is stably integrated into the corresponding genomic locus with almost $100 \%$ efficiency (Kammerer and Cove, 1996; Schaefer, 2001; Cove, 2005, Kamisugi et al., 2005, 2006). A possible explanation for the high rate of HR events in $P$. patens could be a modified recombination mechanism or slight differences in the involved proteins. However, it cannot be excluded that in $P$. patens HR presents the predominant DSB repair mechanism even in the presence of the IR-dependent repair pathway (Kamisugi et al., 2006).

\section{Gene targeting efficiency}

Even when the molecular specifics for the exceptionally high rate of HR in mosses (Trouiller et al., 2007) are still not fully understood, it is evident that $P$. patens is a multicellular plant model organism amenable to targeted gene modifications and reverse genetic analyses. The technique of "gene targeting" specifies the precise genetic modification in an organism using DNA constructs with regions homologous to the target sequence and exploiting the HR system of the cells (Fig. 4). The technology allowing gene targeting in the nuclear DNA of eukaryotes had originally been developed for the genetic modification of yeast (Hinnen et al., 1978). In 1989, a targeted knockout mouse (Mus musculus) was generated by the targeted insertion of a neomycin resistance gene into an endogenous gene in murine embryonic stem cells (Capecchi, 1989; awarded a Nobel Prize in 2007). The first gene targeting experiments in $P$. patens were obtained with a targeting efficiency up to $90 \%$ via HR (Schaefer and Zrÿd, 1997). To ensure a $50 \%$ probability to integrate a foreign DNA construct at the targeted genomic locus, the construct should be flanked by at least regions of $400 \mathrm{bp}$ with perfect sequence homology to the genomic target sequence (Kamisugi et al., 2005). An extension of the flanking regions up to $1 \mathrm{~kb}$ was shown to increase targeted recombination efficiencies to a maximum of $87 \%$ (Kamisugi et al.,
2005). The symmetry of the construct was also reported to affect significantly the recombination probability. Choosing flanking regions with similar sizes at the 5' and 3' end increases the HR events at both sides of the construct (Fig. 4).

Further, a detailed analysis of the targeting efficiency achieved by the transformation of linearised and supercoiled DNA constructs revealed a direct influence of the conformation of the DNAconstruct (Hohe et al., 2004). Transformation of $P$. patens protoplasts with supercoiled DNA led to high numbers of transiently transformed plants and the construct was stably integrated only in $0.2 \%$ of the transformations, whereas transformation with linearised DNA resulted in a lower number of transgenic plants, but in an increase in stable integration to $16 \%$. A plausible explanation for the low number of stable transformants after transfection of circular DNA constructs is the observed extrachromosomal replication of circular plasmids in P. patens over a long period of up to 10 years, when the selection pressure is maintained (Ashton etal., 2000). Furthermore, the effect on the transformation output of the previous cultivation conditions was examined. The addition of ammonium tartrate to the minimal media, for example, reduces the transformation rate by a factor of four under otherwise identical cultivation conditions (Hohe et al., 2004). The high efficiency of gene targeting in P. patens also allows the sequential disruption of individual members of multigene families despite considerable sequence homologies (Hofmann et al., 1999).

\section{Transformation methods}

The transformation of plants depends on a variety of factors, mainly on the characteristics of the species itself and the different transformation techniques that had been established in the last 30 years to transform plants in a reliable manner. However, not all approaches have become a routine in modern laboratory use, because not all fulfil the requested demands. In the following section, we present different transformation techniques for $P$. patens in more detail, focusing on their respective advantages and disadvantages.

\section{Agrobacterium tumefaciens-mediated tranformation}

One of the first and widespread methods for plant transformation is the vector-mediated indirect transfer of DNAusing Agrobacterium tumefaciens (Van Haute et al., 1983). A. tumefaciens is able to transfer foreign DNA via the defined T-DNA region of its Ti-plasmid into plant cells, resulting in a non-directed random integration of the DNA into the plant genome. However, for a long time, P. patens was considered to be "non-transformable" via A. tumefaciens. Only the discovery of new virulent strains enabled the transformation with Agrobacterium (Cove, 2005) and led to the establishment of a transformation protocol (Cove et al., 2009e). The most striking advantage of Agrobacterium-mediated transformation is the generation of only stably transformed mutants and the considerably high transformation rate reaching $10^{-4}$. In contrast to many seed plants, the major disadvantage of this technique is the requirement of protoplasts for the transformation protocol. Additionally, to date, no reports are available on the number of T-DNA integrations into the genome and whether gene targeting via HR is feasible by Agrobacterium-mediated DNA transfer.

\section{Microinjection of DNA}

Another technique for the transformation of plant cells originally 
developed for murine embryonic stem cells (Brinster et al., 1982) involves the injection of foreign DNA by microinjection needles directly into the cell or even directly into the nucleus. For microinjection of DNA, moss filaments have to be cultivated in complete darkness to allow penetration of the cell wall. Even an exposure of dark-grown filaments into the light for 10 minutes prevents proper microinjection. The microinjection needles also have to be introduced into the cells at a precise region basal to the nucleus, because all attempts to inject the cells at the tip region resulted in the bursting of the cells. Microinjection of a green fluorescent protein (GFP) expression construct into $P$. patens protonema tip cells resulted in a transformation rate of approximately $50 \%$ (Brücker et al., 2000). As only the transient GFP expression had been analysed, whether this technique can be used to generate stable transgenic lines and targeted knockout mutants has not been assessed.

\section{Biolistic delivery of DNA}

The first technique especially developed for the transformation of plant cells and that is also applicable for the transformation of $P$. patens, is the particle or gene gun technology that delivers DNA biolistically directly into diverse plant tissues (Klein et al., 1988). The biolistic transformation method is not restricted to specific plants or tissue types and functions with the same efficiency in monocotyledonous and dicotyledonous plants (Sawahel et al., 1992). In P. patens, transient transformation was achieved by shooting DNA-coated gold or tungsten particles onto living protonemal tissue (Cho et al., 1999, Cove et al., 2009c). However, so far, the generation of stable transformants and targeted $P$. patens knockout mutants using the biolistic delivery of DNA has not been reported.

\section{PEG-mediated transformation of protoplasts}

The PEG-mediated direct DNA uptake into protoplasts is the most common technique to transform $P$. patens and to generate targeted knockout lines (Schaefer et al., 1991). To this end, isolation of protoplasts (Cove et al., 2009b) from $P$. patens tissue is required with driselase, a multicomponent enzyme mixture containing cellulase, pectinase, laminarinase, xylanase, and amylase. During the transformation procedure, PEG stabilises the protoplasts and encloses the DNA to allow the negatively charged molecule to pass the cell membrane. After the transformation process, protoplasts can regenerate into cells with an intact cell wall in an osmotically adjusted liquid glucose-containing medium before they are transferred onto selective solid medium supplemented with the respective antibiotic. Transformed plants are selected for twice 14 days on selective medium, interrupted by a period of 14 days on non-selective medium (Egener et al., 2002; Cove et al., 2009b; Liu and Vidali, 2011).

The main advantage of this method is the high transformation efficiency while maintaining a relatively low rate of multiple integrations (Cove, 2000). The transformation of a single knockout construct has been reported to lead on average to 11 copy numbers, ranging from independent integrations at several genomic loci to the integration of concatemers at a single genomic locus (Cove, 2000, Kamisugi et al., 2006) (Fig. 4D). The technique does not require any sophisticated devices and can be easily applied in standard laboratories (Liu and Vidali, 2011). Moreover, it is possible to transform large constructs up to $45 \mathrm{~kb}$ fragment size (Cove et al., 2009d; Liu and Vidali, 2011).

\section{Targeted knockout and knockin strategies}

A targeted gene knockout is a genetic technique to inactivate a gene of interest in an organism by completely replacing or destroying the gene sequence via HR. The resulting knockout mutants are used to infer the function of known, but still uncharacterised, genes. Independently from the organism, the generation of a knockout mutant always follows a similar strategy (Fig. 5A). To generate targeted knockout lines, $P$. patens protoplasts are transfected with a gene disruption construct that harbours a selectable marker cassette within a sequence stretch of the gene of interest. After the first reports on the high $\mathrm{HR}$ rates in $P$. patens (Kammerer and Cove, 1996; Schaefer and Zrÿd, 1997), the proof of concept that HR-based targeted knockout of nuclear genes is feasible was performed by the disruption of the PpFtsZ gene encoding a plastidic protein homologous to the Fts $Z$ protein from Escherichia coli that is essential for bacterial cell division. Given the prokaryotic origin of plastids, the deletion of the PpFtsZgene following a targeted gene knockout strategy abolished chloroplast division and led to the formation of macrochloroplasts (Strepp et al., 1998). In principle, these disruption constructs can be generated from genomic regions, including introns or the respective regions amplified from cDNA. To disrupt several genomic loci independently and to generate mutants with multiple gene deletions, several selection marker cassettes have been established for $P$. patens: G418/neomycin resistance cassette nptIl, hygromycin resistance cassette hpt/aph4, zeomycin resistance cassette zeo, sulfadiazine resistance cassette sul. In addition to the generation of targeted knockout lines $P$. patens allows for the generation of targeted knockin lines, in which genomic regions can be replaced

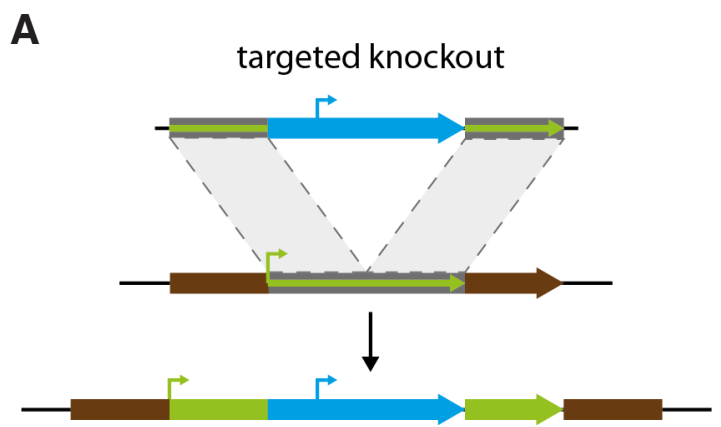

e.g. gene disruption

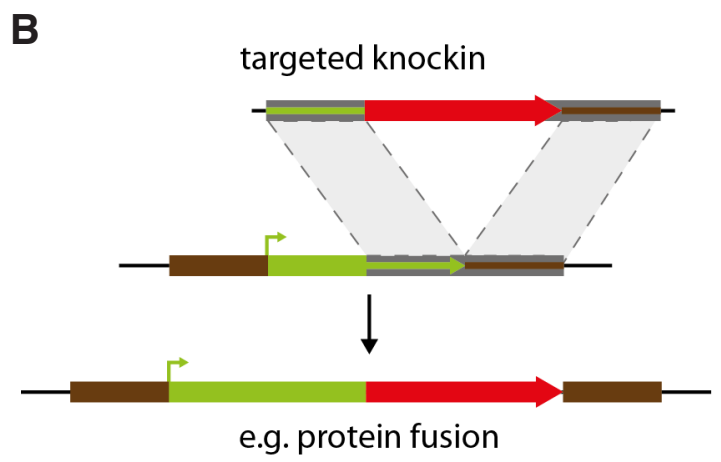

Fig. 5. Principles of knockout and knockin. (A) Integration of a knockout construct. (B) Integration of a knockin construct. 
by homologues from other species for gene complementation studies or to fuse sequences encoding reporter proteins, such as the $\beta$-glucuronidase (GUS) and GFP versions (yellow/cyan/red) (YFP/CFP/RFP), to the coding sequence of the gene of interest to enable localisation and interactions studies (Nakaoka et al., 2012) (Fig. 5B).

\section{Overexpression and transgene expression}

The ectopic and constitutive overexpression of genes is an opposite approach to targeted knockout in the analysis of gene functions. Thereby heterologous or endogenous promoters are used to control the expression of the gene of interest and to increase the amount of gene product. For an ectopic overexpression heterologous promoters, such as the cauliflower mosaic virus (CaMV) 35Spromoter, the bacterial nos promoter, or the rice (Oryza sativa) actin 1 (Act1) promoter, are routinely used in $P$. patens. Quantitative analysis of diverse promoters in $P$. patens revealed that the CaMV $35 S$ promoter, which is widely used for transgene expression in seed plants, does not confer high expression rates in $P$. patens in contrast to the approximately 10 times stronger rice Act1 promoter (Horstmann et al., 2004). Alternatively, endogenous $P$. patenspromoters of housekeeping genes, such as those encoding ubiquitin and actin5, that display a relatively broad and constitutive expression were shown to lead to high overexpression levels of transgenes. Recently, an inducible gene expression system had been established in $P$. patens allowing a temporally controlled expression of transgenes. The system relies on the expression of a transcription factor that is activated upon $\beta$-estradiol binding and subsequently binds to activation sequences located upstream of the transgene, thereby conferring an inducible transgene expression upon $\beta$-estradiol application (Nakaoka et al., 2012).

\section{RNA interference (RNAi)}

In two cases, gene analysis via targeted knockout strategies is labour intensive or even not applicable. In the first case, several genes may possess redundant functions and, therefore, a single knockout of one of these genes will not cause a deviating phenotype. Here, a multiple knockout mutant needs to be generated to shut down redundancy, a time-consuming process, in particular when single genes are disrupted sequentially. In the second case, genes encoding proteins with essential functions cannot be analysed by knockout strategies because the gene disruption would be lethal. In 2003, the mechanisms of RNA interference (RNAi) were shown to be fully functional in $P$. patens that enabled specific knockdown of genes, besides the generation of targeted knockout mutants (Bezanilla et al., 2003). Therefore, a cDNA region of the intended target transcript is cloned into an expression cassette as an inverted repeat that is separated by a loop region. After transcription, this effector construct generates a transcript that folds back into a stem loop structure with a partially double-stranded RNA region perfectly matching the sequence of the target transcript. This double stranded RNA is recognised by the endogenous RNAi machinery and processed into small interfering RNAs (siRNAs) that bind to and mediate the degradation of the cognate target transcript resulting in posttranscriptional gene silencing (Fig. 6). By the selection of a conserved cDNA region shared by different members of a gene family, this approach allows the simultaneous silencing of an entire gene family. Moreover, it is possible to perform gene silencing of two independent targets by two nested inverted repeats, each homologous to one target gene. The inducible overexpression of such an RNAi effector construct was used to silence concurrently the PpFtsZ2-1 gene and a constitutively expressed RFP, with the formation of macrochloroplast and reduced RFP signal (Nakaoka et al., 2012) as a result.

\section{Gene knockdown by artificial microRNAs (miRNAs)}

One drawback of the RNAi approach to study gene function by posttranscriptional gene silencing is the processing of a diverse set of siRNAs from the double-stranded RNA region that might silence off-targets and cause unintended side effects. To circumvent this negative effect, the highly specific endogenous gene silencing mechanism via microRNAs (miRNAs) has been exploited. miRNAs are encoded by miRNA genes (MIR genes) that are transcribed into RNAs that partially fold back into a characteristic hairpin-like structure. In contrast to the double stranded transcripts generated by conventional RNAi effector constructs, only one specific small RNA - the mature miRNA - is processed and released from a defined region of the miRNA precursor transcript. The mature miRNA subsequently mediates the cleavage of its target transcript (Fig. 7). This technique was established in $P$. patens by cloning an expression cassette consisting of the conserved MIR319a gene from $A$. thaliana in which the miRNA generating region was replaced by a sequence designed to target the PpFts $Z 2-1$ gene, while maintaining the overall secondary hairpin-like structure of the natural ath-miR319a precursor transcript (Khraiwesh et al., 2008). Transgenic plants transformed with this artificial miRNA (amiRNA) expression construct correctly processed the PpFtsZ2-1 amiRNA from the precursor. Further, the amiRNA was able to target the PpFtsZ2-1 transcript and caused cleavage and posttranscriptional silencing of the PpFtsZ2-1 transcript. The PpFtsZ2-1 amiRNA was shown to downregulate PpFts $Z 2-1$ transcript levels efficiently causing the formation of macrochloroplasts that phenocopied the

\section{RNAi effector construct}

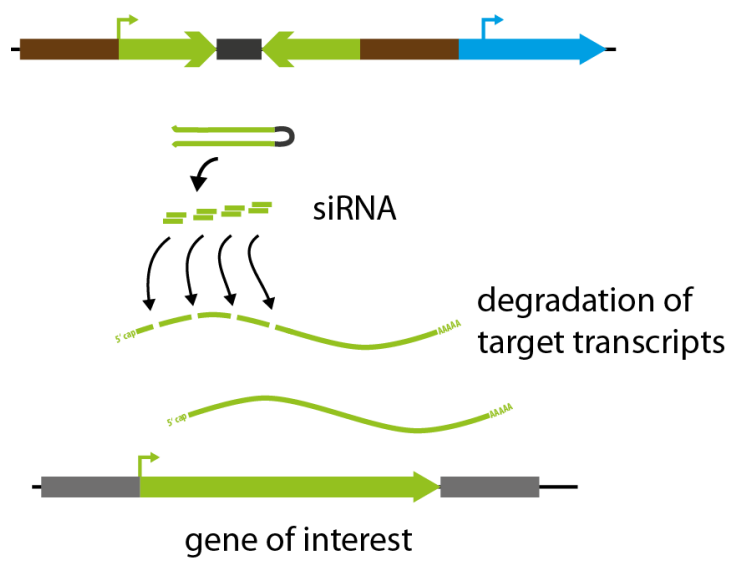

Fig. 6. Principle of RNA interference. Expression of a RNAi effector construct with inverted repeats homologous to an endogenous target gene leading to the expression of a double-stranded RNA stem loop that is processed into a diverse set of siRNAs that mediates target transcript degradation. 
reported phenotype for PpFtsZ2-1 knockout mutants (Strepp et al., 1998).

\section{Forward or reverse genetics to address biological questions in P. patens}

Currently reverse genetics is the method of choice for functional gene studies in $P$. patens because it is the sole model plant in which gene disruption by gene targeting is efficiently practicable. Thereby, the selection of genes of interest that will be disrupted is based on bioinformatic predictions or experimental indications. Nevertheless, as approximately $1 / 3$ of the $P$. patens transcripts do not show significant homology to genes from other species (Nishiyama et al., 2003; Lang et al., 2005), there is a particular demand for unbiased forward genetics screens to determine novel gene functions.

Forward genetics is the classical approach to link genes to a particular phenotype and, thus, to obtain information about gene functions. Mutants with altered phenotypes are isolated from saturated mutant collections that had been generated by the application of mutagenic agents and the underlying mutation is identified and isolated by, for instance, map-based cloning (Peters et al., 2003).

Chemical or UV mutagenesis is feasible for $P$. patens (Cove et al., 2009a) and mutants generated by methylnitronitrosoguanidine mutagenesis of spores exhibiting alterations in gravitropism were isolated (Knight et al., 1991), but, to our knowledge, the underlying mutations causing the phenotypic deviations could not be identified so far. One reason is the lack of sufficient molecular markers available from different $P$. patens ecotypes that enable map-based cloning of the affected genomic loci in such mutants. Nevertheless, a first set of 110 simple sequence repeats (SSR) markers displaying size polymorphisms between the Gransden ecotype and the Villersexel-K3 ecotype could be identified (von Stackelberg et al., 2006). Subsequently, 42 SSR markers were combined with additional 1, 378 amplified fragment length polymorphism (AFLP) markers identified from a mapping population generated by the crossing of the Gransden and the Villersexel-K3 ecotype to 31 linkage groups (Kamisugi et al., 2008). In addition, after the release of the complete genome sequence of the $P$. patens Gransden ecotype (Rensing et al., 2008), this combined SSR and AFLP map could be anchored to the genomic sequence of 94 out of 2,106 sequence scaffolds (genome version 1.1). Still, this combined and genome-anchored genetic map needs to be refined for feasible map-based cloning in forward genetic approaches. Besides chemical or UV mutagenesis, mutant collections of $P$. patens have been generated by transformation of tagged insertion constructs derived from gDNA or cDNA libraries that are suitable for integration by HR. In a first approach, a genomic DNA library was generated and tagged with shuttle mutagenesis and mini transposons containing selectable marker genes or an additional promoterless uidA(GUS) reporter gene construct (gene trap) (Nishiyama et al., 2000). Upon transformation into $P$. patens and selection, a total of 5,264 stably transformed transgenic plants were recovered out of which 203 mutants showed developmental and morphological deviations. In plants stably transformed with gene trapping constructs, GUS activity was detected histochemically in different tissues, including young leaves, apical cells of young buds, and chloronema and caulonema cells. Related to that, enhancer trap lines have been generated in which a CaMV $35 S$ minimal promoter was fused to artificial miRNA construct

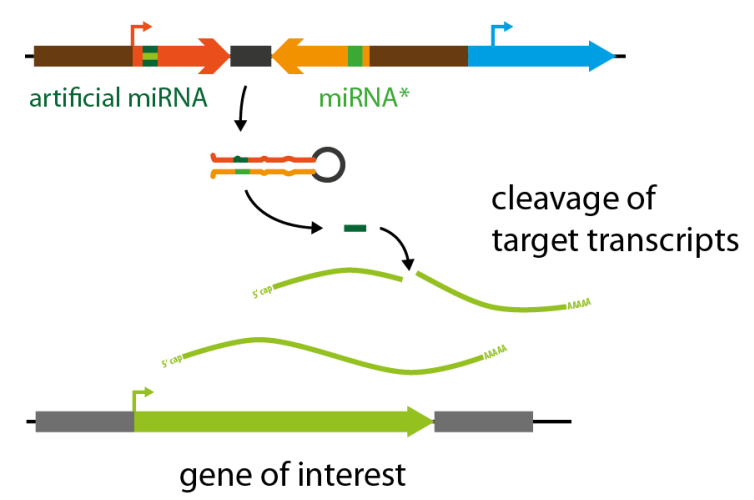

Fig. 7. Gene knockdown by artificial microRNAs. Expression of artificial miRNA precursors harbouring miRNA complementary to the target transcript resulting in the processing of the amiRNA that mediates target transcript cleavage.

the uidA reporter gene to screen for adjacent enhancer elements (Hiwatashi et al., 2001).

Another approach followed a similar strategy to generate tagged insertion mutants, but selectable marker genes were introduced into a cDNA library by transposon-mediated shuttle mutagenesis (Egener et al., 2002). The tagged insertion constructs derived from cDNA libraries were assumed to integrate preferably by HR into transcribed genes and those derived from gDNA will integrate across the whole genome. High-throughput transformation of random and defined pools of cDNA-derived tagged insertion constructs resulted in a mutant collection of 65,198 stably transformed plants that have been grouped into 16 categories according to deviations in development, morphology, physiology, and growth parameters (Schween et al., 2005). Phenotypically catalogued mutants were deposited into a searchable database (mossDB) and cryopreserved for long-term storage. Although the generation of mutant collections using tagged insertion constructs derived from gDNA and cDNA libraries resulted in a high rate of various deviating phenotypes in $P$. patens reports on the identification of the affected genes are still missing and might be due to several causes. (i) Molecular analysis of tagged insertion mutants revealed several independent integration loci in the genome either because of illegitimate integration events or integration of several independent constructs by HR, hampering the identification of the mutation causing the phenotype. (ii) Integration of concatenated constructs into a genomic locus was observed (Fig. 4D) and, consequently, polymerase chain reaction (PCR)-based techniques to isolate flanking regions, such as TAIL-PCR, adapter-ligation-mediated PCR, or inverse PCR, are not applicable. (iii) The 5'- and 3'-flanking regions of transformed constructs are homologous to endogenous regions and, therefore, need to be discriminated from chromosomal sequences flanking the insertion site in sequencing results of plasmid rescue or PCR-based methods mentioned above. (iv) Co-transformed vector backbones may integrate into the genomic DNA by IR and may underlie the altered phenotype.

A promising alternative method to identify new genes by forward genetics approaches uses next-generation sequencing technology for the complete sequencing of nuclear DNA from the wild type and mutants and subsequent advanced bioinformatic analysis 
(Nordström et al., 2013). This method allows the simultaneous detection of mutations and sequence recovery of the corresponding loci. With decreasing sequencing costs, next-generation sequencing can turn into a high-throughput technology to analyse existing or new $P$. patens mutants generated by diverse forward genetics approaches.

\section{Future prospects}

Further progress in the identification of molecular markers will refine the genetic map of $P$. patens to enable map-based cloning of mutations underlying the altered phenotypes of mutants produced by forward genetics approaches. In addition, the generation of unbiased mutant collections by the transformation of DNA constructs that serve as molecular anchors for mutant analysis are highly desirable. Protocols for genetic crosses in $P$. patens have to be established and used more frequently to exploit the experimental power of plant genetics. The already established International Moss Stock Center (IMSC; www.moss-stock-center. org) opens the way to provide extensive $P$. patens mutant collections for forward or reverse genetics in a manner comparable to the available $A$. thaliana resources. The IMSC currently comprises 39 different ecotypes of $P$. patens, Physcomitrium, and Funaria and 64 additional transgenic $P$. patens lines, mainly representing published targeted knockout lines stored in cryopreservation. In the future, all reported transgenic $P$. patens lines should be stored at the IMSC to extend it to a versatile resource providing mutants for $P$. patens genetics.

\section{Acknowledgements}

We gratefully acknowledge financial support from the German Research Foundation (Deutsche Forschungsgemeinschaft, Research Grants FR 1677/3-1 and FR1677/3-2).

\section{References}

ADAMS M D, KELLEY J M, GOCAYNE J D, DUBNICK M, POLYMEROPOULOS $\mathrm{M} \mathrm{H}$, XIAO H, MERRIL C R, WU A, OLDE B, MORENO R F, KERLAVAGE A R, MCCOMBIE W R, VENTER J C (1991). Complementary DNA sequencing: expressed sequence tags and human genome project. Science 252: 1651-1656.

ADDO-QUAYE C, SNYDER J A, PARK Y B, LI Y-F, SUNKAR R, AXTELL M J (2009). Sliced microRNA targets and precise loop-first processing of MIR319 hairpins revealed by analysis of the Physcomitrella patens degradome. RNA 15:2112-2121.

ARIF M A, FATTASH I, MA Z, CHO S H, BEIKE A K, RESKI R, AXTELL M J, FRANK W (2012). DICER-LIKE3 activity in Physcomitrella patens DICER-LIKE4 mutants causes severe developmental dysfunction and sterility. Mol Plant 5: 1281-1294.

ASHTON N W, CHAMPAGNE C E M, WEILER T, VERKOCZY L K (2000). The bryophyte Physcomitrella patens replicates extrachromosomal transgenic elements. New Phytol 146: 391-402.

ASHTON N W, GRIMSLEY N H, COVE D J (1979). Analysis of gametophytic development in the moss, Physcomitrella patens, using auxin and cytokinin resistant mutants. Planta 144: 427-435.

AXTELL M J, JAN C, RAJAGOPALAN R, BARTEL D P (2006). A two-hit trigger for siRNA biogenesis in plants. Cell 127: 565-577.

BANKS J A, NISHIYAMA T, HASEBE M, BOWMAN J L, GRIBSKOV M, DEPAMPHILIS C, ALBERT V A, AONO N, AOYAMA T, AMBROSE B A et al. (2011). The Selaginella genome identifies genetic changes associated with the evolution of vascular plants. Science 332: 960-963.

BEIKE A K, HORST N A, RENSING S A (2010). Axenic bryophyte in vitro cultivation. $J$ Endocytobiosis Cell Res 20: 102-108.

BEVAN M W, FLAVELL R B, CHILTON M.D (1983). A chimaeric antibiotic resistance gene as a selectable marker for plant cell transformation. Nature 304: 184-187.
BEZANILLA M, PAN A, QUATRANO R S (2003). RNA interference in the moss Physcomitrella patens. Plant Physiol 133: 470-474.

BRINSTER R L, CHEN H Y, WARREN R, SARTHY A, PALMITER R D (1982). Regulation of metallothionein--thymidine kinase fusion plasmids injected into mouse eggs. Nature 296: 39-42.

BRITT A B, MAY G D (2003). Re-engineering plant gene targeting. Trends Plant Sci 8: 90-95.

BRÜCKER G, ZEIDLERM, KOHCHIT, HARTMANN E, LAMPARTERT (2000). Microinjection of heme oxygenase genes rescues phytochrome-chromophore-deficient mutants of the moss Ceratodon purpureus. Planta 210: 529-535.

CAPECCHI M R (1989). The new mouse genetics: altering the genome by gene targeting. Trends Genet 5: 70-76.

CHO S H, ADDO-QUAYE C, CORUH C, ARIF M A, MA Z, FRANK W, AXTELL M J (2008). Physcomitrella patens DCL3 is required for 22-24 nt siRNA accumulation, suppression of retrotransposon-derived transcripts, and normal development PLoS Genet 4: e1000314.

CHO S-H, CHUNG Y-S, CHO S-K, RIM Y-W, SHIN J-S (1999). Particle bombardment mediated transformation and GFP expression in the moss Physcomitrella patens. Mol Cells 9: 14-19.

COLLINS F S, LANDER E S, ROGERS J, WATERSTON R H, INTERNATIONAL HUMAN GENOME SEQUENCING CONSORTIUM (2004). Finishing the euchromatic sequence of the human genome. Nature 431: 931-945.COVED (2000). The moss, Physcomitrella patens. J Plant Growth Regul 19: 275-283.

COVE D (2005). The moss Physcomitrella patens. Annu Rev Genet 39: 339-358

COVE D J, PERROUD P-F, CHARRON A J, MCDANIEL $S$ F, KHANDELWAL A QUATRANO R S (2009a). Chemical and UV mutagenesis of spores and protonemal tissue from the moss Physcomitrella patens. Cold Spring Harb Protoc 2009: pdb.prot5142.

COVE D J, PERROUD P-F, CHARRON A J, MCDANIEL S F, KHANDELWAL A, QUATRANO R S (2009b). Isolation and regeneration of protoplasts of the moss Physcomitrella patens. Cold Spring Harb Protoc 2009: pdb.prot5140.

COVE D J, PERROUD P-F, CHARRON A J, MCDANIEL S F, KHANDELWAL A, QUATRANO R S (2009c). Transformation of moss Physcomitrella patens gametophytes using a biolistic projectile delivery system. Cold Spring Harb Protoc 2009: pdb.prot5145.

COVE D J, PERROUD P-F, CHARRONA J, MCDANIEL S F, KHANDELWALA, QUATRANO R S (2009d). Transformation of the moss Physcomitrella patens using direct DNA uptake by protoplasts. Cold Spring Harb Protoc 2009: pdb.prot5143.

COVE D J, PERROUD P-F, CHARRON A J, MCDANIEL S F, KHANDELWAL A, QUATRANO R S (2009e). Transformation of the moss Physcomitrella patens using T-DNA mutagenesis. Cold Spring Harb Protoc 2009: pdb.prot5144.

CUMING A C, CHO S H, KAMISUGI Y, GRAHAM H, QUATRANO R S (2007). Microarray analysis of transcriptional responses to abscisic acid and osmotic, salt, and drought stress in the moss, Physcomitrella patens. New Phytol 176: 275-287.

DECKER E L, RESKI R (2004). The moss bioreactor. Curr Opin Plant Biol7: 166-170.

DECKER E L, RESKI R (2012). Glycoprotein production in moss bioreactors. Plant Cell Rep 31: 453-460.

DECKER E L, FRANK W, SARNIGHAUSEN E, RESKI R (2006). Moss systems biology en route: phytohormones in Physcomitrella development. Plant Biol (Stuttg) 8: 397-405.

EGENER T, GRANADO J, GUITTON M-C, HOHE A, HOLTORF H, LUCHT J M, RENSING S A, SCHLINK K, SCHULTE J, SCHWEEN G, ZIMMERMANN S, DUWENIG E, RAK B, RESKI R (2002). High frequency of phenotypic deviations in Physcomitrella patens plants transformed with a gene-disruption library. BMC Plant Biol 2: 6.

FAYE L, GOMORD V (2010). Success stories in molecular farming--a brief overview. Plant Biotechnol J 8: 525-528.

FIRE A, XU S, MONTGOMERY M K, KOSTAS S A, DRIVER S E, MELLO C C (1998) Potent and specific genetic interference by doublestranded RNAin Caenorhabditis elegans. Nature 391: 806-811.

FISCHER R, STOGER E, SCHILLBERG S, CHRISTOU P, TWYMAN R M (2004). Plant-based production of biopharmaceuticals. Curr Opin Plant Biol 7: 152-158.

FLEISCHMANN R D, ADAMS M D, WHITE O, CLAYTON R A, KIRKNESS E F, KERLAVAGE A R, BULT C J, TOMB J.F, DOUGHERTY B A, MERRICK J M et al. (1995). Wholegenome random sequencing and assembly of Haemophilus 
influenzae Rd. Science 269: 496-512

FLOYD S K, BOWMAN J L (2007). The ancestral developmental tool kit of land plants. Int J Plant Sci 168: 1-35.

FOETISCH K, WESTPHAL S, LAUER I, RETZEK M, ALTMANN F KOLARICH D, SCHEURER S, VIETHS S (2003). Biological activity of IgE specific for crossreactive carbohydrate determinants. J Allergy Clin Immunol 111: 889-896.

FRALEY R T, ROGERS S G, HORSCH R B, SANDERS P R, FLICK J S, ADAMS S P, BITTNER M L, BRAND L A, FINK C L, FRY J S, GALLUPPI G R, GOLDBERG $S B$, HOFFMANN N L, WOO S C (1983). Expression of bacterial genes in plant cells. Proc Natl Acad Sci USA 80: 4803-4807.

FRANK W, RATNADEWI D, RESKI R (2005). Physcomitrella patens is highly tolerant against drought, salt and osmotic stress. Planta 220: 384-394.

GIRKE T, SCHMIDT H, ZÄHRINGER U, RESKI R, HEINZ E (1998). Identification of a novel $\triangle 6$-acyl-group desaturase by targeted gene disruption in Physcomitrella patens. Plant J 15: 39-48.

GOMORD V, FAYE L (2004). Posttranslational modification of therapeutic proteins in plants. Curr Opin Plant Biol 7: 171-181

GORBUNOVA V, LEVY AA (1999). How plants make ends meet: DNA doublestrand break repair. Trends Plant Sci 4: 263-269.

HARRISON C J, ROEDER A H K, MEYEROWITZ E M, LANGDALE J A (2009). Local cues and asymmetric cell divisions underpin body plan transitions in the moss Physcomitrella patens. Curr Biol 19: 461-471.

HINNEN A, HICKS J B, FINK G R (1978). Transformation of yeast. Proc Natl Acad Sci USA 75: 1929-1933.

HIWATASHIY, NISHIYAMAT, FUJITAT, HASEBE M (2001). Establishment of gene-trap and enhancer-trap systems in the moss Physcomitrella patens. Plant J28: 105-116.

HOFMANN A H, CODÓN A C, IVASCU C, RUSSO V E A, KNIGHT C, COVE D, SCHAEFER D G, CHAKHPARONIAN M, ZRŸD J-P (1999). A specific member of the $C a b$ multigene family can be efficiently targeted and disrupted in the moss Physcomitrella patens. Mol Gen Genet 261: 92-99.

HOHE A, DECKER E L, GORR G, SCHWEEN G, RESKI R (2002a). Tight control of growth and cell differentiation in photoautotrophically growing moss (Physcomitrella patens) bioreactor cultures. Plant Cell Rep 20: 1135-1140.

HOHEA, EGENER T, LUCHT J M, HOLTORF H, REINHARD C, SCHWEEN G, RESKI $R$ (2004). An improved and highly standardised transformation procedure allows efficient production of single and multiple targeted gene-knockouts in a moss, Physcomitrella patens. Curr Genet 44: 339-347.

HOHE A, RENSING S A, MILDNER M, LANG D, RESKI R (2002b). Day length and temperature strongly influence sexual reproduction and expression of a novel MADS-box gene in the moss Physcomitrella patens. Plant Biol 4: 595-602.

HORSTMANN V, HUETHER C M, JOST W, RESKI R, DECKER E L (2004). Quantitative promoter analysis in Physcomitrella patens: a set of plant vectors activating gene expression within three orders of magnitude. BMC Biotechnol 4: 13.

HUETHER C M, LIENHART O, BAURA, STEMMER C, GORR G, RESKI R, DECKER $E L$ (2005). Glyco-engineering of moss lacking plant-specific sugar residues. Plant Biol 7: 292-299.

KAMISUGI Y, CUMING A C, COVE D J (2005). Parameters determining the efficiency of gene targeting in the moss Physcomitrella patens. Nucleic Acids Res 33: e173.

KAMISUGI Y, SCHLINK K, RENSING S A, SCHWEEN G, VON STACKELBERG M, CUMING A C, RESKI R, COVE D J (2006). The mechanism of gene targeting in Physcomitrella patens: homologous recombination, concatenation and multiple integration. Nucleic Acids Res 34: 6205-6214.

KAMISUGI Y, VON STACKELBERG M, LANG D, CARE M, RESKI R, RENSING S A, CUMING A C (2008). A sequence-anchored genetic linkage map for the moss, Physcomitrella patens. Plant J 56: 855-866

KAMMERER W, COVE D J (1996). Genetic analysis of the effects of re-transformation of transgenic lines of the moss Physcomitrella patens. Mol Gen Genet250:380-382.

KAUL S, KOO H L, JENKINS J, RIZZO M, ROONEY T, TALLON L J, FELDBLYUM T, NIERMAN W, BENITO M.I, LIN X et al. (2000). Analysis of the genome sequence of the flowering plant Arabidopsis Thaliana. Nature 408: 796-815.

KHRAIWESH B, OSSOWSKI S, WEIGEL D, RESKI R, FRANK W (2008). Specific gene silencing by artificial microRNAs in Physcomitrella patens: An alternative to targeted gene knockouts. Plant Physiol 148: 684-693.

KLEIN T M, FROMM M, WEISSINGER A, TOMES D, SCHAAF S, SLETTEN M, SANFORD J C (1988). Transfer of foreign genes into intact maize cells with highvelocity microprojectiles. Proc Natl Acad Sci USA 85: 4305-4309.

KNIGHT C D, FUTERS T S, COVE D J (1991). Genetic analysis of a mutant class of Physcomitrella patens in which the polarity of gravitropism is reversed. Mol Gen Genet 230: 12-16.

KOPRIVOVAA, STEMMER C, ALTMANN F, HOFFMANN A, KOPRIVA S, GORR G, RESKI R, DECKER E L (2004). Targeted knockouts of Physcomitrella lacking plant-specific immunogenic N-glycans. Plant Biotechnol J 2: 517-523.

LANG D, EISINGER J, RESKI R, RENSING S A (2005). Representation and highquality annotation of the Physcomitrella patens transcriptome demonstrates a high proportion of proteins involved in metabolism in mosses. Plant Biol 7: 238-250.

LEHTONEN M T, AKITA M, FRANK W, RESKI R, VALKONEN J P T (2012). Involvement of a class III peroxidase and the mitochondrial protein TSPO in oxidative burst upon treatment of moss plants with a fungal elicitor. Mol Plant-Microbe Interact 25: 363-371.

LIUY-C, VIDALI L (2011). Efficient polyethylene glycol (PEG) mediated transformation of the moss Physcomitrella patens. J Vis Exp 50: e2560.

LONG Z, WANG S-Y, NELSONN (1989). Cloning and nucleotide sequence analysis of genes coding for the major chlorophyll-binding protein of the moss Physcomitrella patens and the halotolerant alga Dunaliella salina. Gene 76: 299-312.

LUCUMI A, POSTEN C, PONS M-N (2005). Image analysis supported moss cell disruption in photo-bioreactors. Plant Biol 7: 276-282.

MENAND B, CALDER G, DOLAN L (2007). Both chloronemal and caulonemal cells expand by tip growth in the moss Physcomitrella patens. J Exp Bot58: 1843-1849.

MERCHANT S S, PROCHNIK S E, VALLON O, HARRIS E H, KARPOWICZ S J, WITMAN GB, TERRYA, SALAMOVA, FRITZLAYLIN LK, MARÉCHALDROUARD $L$ et al. (2007). The Chlamydomonas genome reveals the evolution of key animal and plant functions. Science 318: 245-250.

MULLIS K, FALOONA F, SCHARF S, SAIKI R, HORN G, ERLICH H (1986). Specific enzymatic amplification of DNA in vitro: the polymerase chain reaction. Cold Spring Harbor Symp Quant Biol 51: 263-273.

NAKAOKA Y, MIKI T, FUJIOKA R, UEHARA R, TOMIOKA A, OBUSE C, KUBO M, HIWATASHI Y, GOSHIMA G (2012). An inducible RNA interference system in Physcomitrella patens reveals a dominant role of augmin in phragmoplast microtubule generation. Plant Cell 24: 1478-1493.

NISHIYAMA T, FUJITA T, SHIN-I T, SEKI M, NISHIDE H, UCHIYAMA I, KAMIYA A CARNINCI P, HAYASHIZAKI Y, SHINOZAKI K, KOHARA Y, HASEBE M (2003). Comparative genomics of Physcomitrella patens gametophytic transcriptome and Arabidopsis Thaliana: implication for land plant evolution. Proc Natl Acad Sci USA 100: 8007-8012.

NISHIYAMAT, HIWATASHI Y, SAKAKIBARAK, KATO M, HASEBE M (2000). Tagged mutagenesis and gene-trap in the moss, Physcomitrella patens by shuttle mutagenesis. DNA Res 7: 9-17.

NISHIYAMAT, MIYAWAKIK, OHSHIMAM, THOMPSONK, NAGASHIMAA, HASEBE M, KURATA T (2012). Digital gene expression profiling by 5'-end sequencing of cDNAs during reprogramming in the moss Physcomitrella patens. PLoS ONE 7: e36471.

NORDSTRÖM K J V, ALBANI M C, JAMES G V, GUTJAHR C, HARTWIG B, TURCK F, PASZKOWSKI U, COUPLAND G, SCHNEEBERGERK (2013). Mutation identification by direct comparison of whole-genome sequencing data from mutant and wild-type individuals using k-mers. Nat Biotechnol 31: 325-330.

PÂQUES F, HABER J E (1999). Multiple pathways of recombination induced by doublestrand breaks in Saccharomyces cerevisiae. Microbiol Mol Biol Rev63:349-404

PARSONS J, ALTMANN F, ARRENBERG C K, KOPRIVOVA A, BEIKE A K, STEMMER C, GORR G, RESKI R, DECKER E L (2012). Moss-based production of asialo-erythropoietin devoid of Lewis $A$ and other plant-typical carbohydrate determinants. Plant Biotechnol J 10: 851-861.

PETERS J L, CNUDDE F, GERATS T (2003). Forward genetics and map-based cloning approaches. Trends Plant Sci 8: 484-491.

PIRES N D, DOLAN L (2012). Morphological evolution in land plants: new designs with old genes. Philos Trans R Soc B-Biol Sci 367: 508-518.

PUCHTAH (2002). Gene replacement by homologous recombination in plants. Plant Mol Biol 48: 173-182.

PUCHTA H (2005). The repair of doublestrand breaks in plants: mechanisms and consequences for genome evolution. J Exp. Bot 56: 114.

RASKIN I, RIBNICKY D M, KOMARNYTSKY S, ILIC N, POULEV A, BORISJUK N 
BRINKER A, MORENO D A, RIPOLL C, YAKOBY N, O'NEAL J M, CORNWELL T, PASTOR I, FRIDLENDER B (2002). Plants and human health in the twenty-first century. Trends Biotechnol 20: 522-531.

RENSING S A, FRITZOWSKY D, LANG D, RESKI R (2005). Protein encoding genes in an ancient plant: analysis of codon usage, retained genes and splice sites in a moss, Physcomitrella patens. BMC Genomics 6: 43.

RENSING S A, LANG D, ZIMMER A D, TERRY A, SALAMOV A, SHAPIRO H, NISHIYAMA T, PERROUD P-F, LINDQUIST E A, KAMISUGI Y et al. (2008). The Physcomitrella genome reveals evolutionary insights into the conquest of land by plants. Science 319: 64-69.

RENSING SA, ROMBAUTSS, VANDE PEERY, RESKIR (2002). Moss transcriptome and beyond. Trends Plant Sci 7: 535-538.

RESKI R (1998). Development, genetics and molecular biology of mosses. Bot Acta 111: 1-15.

RESKI R, FAUST M, WANG X-H, WEHE M, ABEL W O (1994). Genome analysis of the moss Physcomitrella patens (Hedw.) B.S.G. Mol Gen Genet 244: 352-359.

RESKI R, REYNOLDS S, WEHE M, KLEBER-JANKE T, KRUSE S (1998). Moss (Physcomitrella patens) expressed sequence tags include several sequences which are novel for plants. Bot Acta 111: 143-149.

RICHARDT S, TIMMERHAUS G, LANG D, QUDEIMAT E, CORREAALG G, RESKI R, RENSING S A, FRANK W (2010). Microarray analysis of the moss Physcomitrella patens reveals evolutionarily conserved transcriptional regulation of salt stress and abscisic acid signalling. Plant Mol Biol 72: 27-45.

ROTH N, KLIMESCH J, DUKOWIC-SCHULZE S, PACHER M, MANNUSS A, PU$\mathrm{CHTA} \mathrm{H}$ (2012). The requirement for recombination factors differs considerably between different pathways of homologous double-strand break repair in somatic plant cells. Plant J 72: 781-790.

SAWAHEL W, ONDE S, KNIGHT C, COVE D (1992). Transfer of foreign DNA into Physcomitrella patens protonemal tissue by using the gene gun. Plant Mol Biol Rep 10: 314-315.

SCHAEFER D, ZRŸD J-P, KNIGHT C D, COVE D J (1991). Stable transformation of the moss Physcomitrella patens. Mol Gen. Genet 226: 418-424.

SCHAEFER D G (2001). Gene targeting in Physcomitrella patens. Curr Opin Plant Biol 4: 143-150.

SCHAEFERD G, ZRŸDJ.P(1997). Efficient gene targeting in the moss Physcomitrella patens. Plant J 11: 1195-1206.

SCHWEEN G, EGENER T, FRITZOWSKY D, GRANADO J, GUITTON M-C, HARTMANN N, HOHE A, HOLTORF H, LANG D, LUCHT J M, REINHARD C, RENSING S A, SCHLINK K, SCHULTE J, RESKI R (2005). Large-scale analysis of 73329 Physcomitrella plants transformed with different gene disruption libraries: production parameters and mutant phenotypes. Plant Biol 7: 228-237.
SCHWEEN G, HOHE A, KOPRIVOVA A, RESKI R (2003). Effects of nutrients, cell density and culture techniques on protoplast regeneration and early protonema development in a moss, Physcomitrella patens. J Plant Physiol 160: 209-212.

SMITH L M, SANDERS J Z, KAISER R J, HUGHES P, DODD C, CONNELL C R, HEINER C, KENT S B H, HOOD LE (1986). Fluorescence detection in automated DNA sequence analysis. Nature 321: 674-679.

STREPP R, SCHOLZ S, KRUSE S, SPETH V, RESKI R (1998). Plant nuclear gene knockout reveals a role in plastid division for the homolog of the bacterial cell division protein FtsZ, an ancestral tubulin. Proc NatlAcad Sci USA 95: 4368-4373.

SUGIURA C, SUGITA M (2004). Plastid transformation reveals that moss tRNA ${ }^{\text {Arg. }}$ CCG is not essential for plastid function. Plant $J$ 40: 314-321.

SUGIURA C, KOBAYASHI Y, AOKI S, SUGITA C, SUGITA M (2003). Complete chloroplast DNA sequence of the moss Physcomitrella patens: evidence for the loss and relocation of rpoA from the chloroplast to the nucleus. Nucleic Acids Res 31: 5324-5331.

SUNG P, KLEIN H (2006). Mechanism of homologous recombination: mediators and helicases take on regulatory functions. Nat Rev Mol Cell Biol 7: 739-750.

TERASAWA K, ODAHARA M, KABEYA Y, KIKUGAWA T, SEKINE Y, FUJIWARA M, SATO N (2007). The mitochondrial genome of the moss Physcomitrella patens sheds new light on mitochondrial evolution in land plants. Mol Biol Evol24:699-709.

THE ARABIDOPSIS INFORMATION RESOURCE (2013) Genome Annotation Carnegie Institution of Washington, Stanford.

TROUILLER B, CHARLOT F, CHOINARD S, SCHAEFER D G, NOGUÉ F (2007). Comparison of gene targeting efficiencies in two mosses suggests that it is a conserved feature of Bryophyte transformation. Biotechnol Lett 29: 1591-1598.

VAN HAUTE E, JOOS H, MAES M, WARREN G, VAN MONTAGU M, SCHELL $J$ (1983). Intergeneric transfer and exchange recombination of restriction fragments cloned in pBR322: a novel strategy for the reversed genetics of Ti plasmids of Agrobacterium tumefaciens. EMBO J 2: 411-418.

VON STACKELBERG M, RENSING S A, RESKI R (2006). Identification of genic moss SSR markers and a comparative analysis of twenty-four algal and plant gene indices reveal species-specific rather than group-specific characteristics of microsatellites. BMC Plant Biol 6: 9.

ZAMBRYSKI P, JOOS H, GENETELLO C, LEEMANS J, VAN MONTAGU M, SCHELL $J$ (1983). Ti plasmid vector for the introduction of DNA into plant cells without alteration of their normal regeneration capacity. EMBO J 2: 2143-2150.

ZIMMER AD, LANG D, BUCHTAK, ROMBAUTS S, NISHIYAMA T, HASEBE M, VAN DE PEER Y, RENSING SA, RESKI R (2013). Reannotation and extended community resources for the genome of the non-seed plant Physcomitrella patens provide insights into the evolution of plant gene structures and functions. BMC Genomics 14: 498 


\title{
Further Related Reading, published previously in the Int. J. Dev. Biol.
}

DNA methylation establishment during oocyte growth: mechanisms and significance Shin-Ichi Tomizawa, Joanna Nowacka-Woszuk and Gavin Kelsey Int. J. Dev. Biol. (2012) 56: 867-875

Dynamical patterning modules in plant development and evolution Valeria Hernández-Hernández, Karl J. Niklas, Stuart A. Newman and Mariana Benítez Int. J. Dev. Biol. (2012) 56: 661-674

\author{
Evolution and pleiotropy of TRITHORAX function in Arabidopsis \\ Zoya Avramova \\ Int. J. Dev. Biol. (2009) 53: 371-381
}

José-Antonio Campos-Ortega (1940-2004) and his scientific work - a personal perspective Elisabeth Knust and Rainer Hertel

Int. J. Dev. Biol. (2009) 53: 1193-1203

Analysis of a homologue of the adducin head gene which is a potential target for the Dictyostelium STAT protein Dd-STATa Ryota Aoshima, Rieko Hiraoka, Nao Shimada and Takefumi Kawata

Int. J. Dev. Biol. (2006) 50: 523-532

Plant tropisms: providing the power of movement to a sessile organism C. Alex Esmon, Ullas V. Pedmale and Emmanuel Liscum Int. J. Dev. Biol. (2005) 49: 665-674

Plant microRNAs and development

Sara Jover-Gil, Héctor Candela and María-Rosa Ponce Int. J. Dev. Biol. (2005) 49: 733-744

Long-range signalling in plant reproductive development

Paula Suárez-López

Int. J. Dev. Biol. (2005) 49: 761-771

Quantitative gene expression profiling reveals a fetal hepatic phenotype of murine ES-derived hepatocytes

Andrea Jochheim, Tina Hillemann, Gabriela Kania, Jennifer Scharf, Masoumeh Attaran, Michael P Manns, Anna M Wobus and Michael Ott

Int. J. Dev. Biol. (2004) 48: 23-29

5 yr ISI Impact Factor $(2011)=2.959$
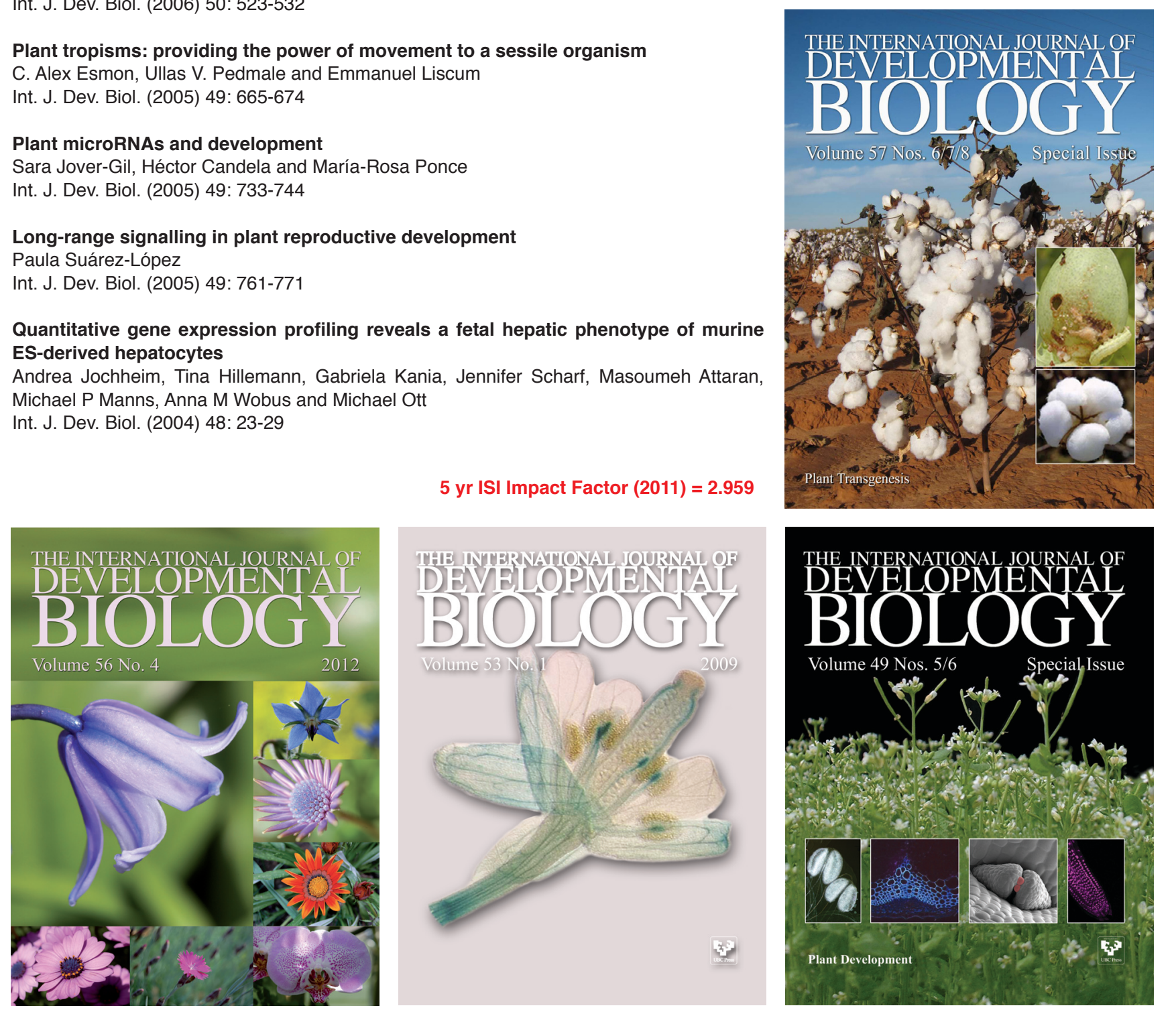